\title{
Morphometric Characteristics and Feeding Habits of Five Commercial Fish Species of the Libga Reservoir in the Northern Region of Ghana
}

\author{
Kuebutornye FKA ${ }^{1-6}$, Akongyuure DN7* and Alhassan EH7 \\ ${ }^{1}$ College of Fishery, Guangdong Ocean University, China \\ 2Shenzhen Institute of Guangdong Ocean University, China \\ ${ }^{3}$ Guangdong Provincial Key Laboratory of Pathogenic Biology and Epidemiology for
} Aquatic Animals, China

${ }^{4}$ Guangdong Provincial Engineering Research Center for Aquatic Animal Health Assessment, China

5Shenzhen Public Service Platform for Evaluation of Marine Economic Animal Seedings, China

${ }^{6}$ Guangdong Key Laboratory of Control for Diseases of Aquatic Economic Animals, China

${ }^{7}$ Department of Fisheries and Aquatic Resources Management, University for Development Studies, Ghana

*Corresponding author: Daniel Nsoh Akongyuure, Department of Fisheries and Aquatic Resources Management, University for Development Studies, Tamale, Ghana, Tel: +233240494916; Email: akongyuure2012@gmail.com

\section{Abstract}

Knowledge of the growth size of fishes and what they feed provide basis for the choice of fish species for culture which is very essential for successful aquaculture. This study was conducted to assess the size and feeding habits of Auchenoglanis occidentalis, Brycinus imberi, Sarotherodon galilaeus, Oreochromis niloticus and Marcusenius abadii of the Libga reservoir. Samples were purchased from catches of local fishermen from the reservoir and assessed once every month from December 2015 to May 2016. Fish samples were preserved with ice and immediately transported to the laboratory for morphometric data and stomach content analysis. A total of 223 specimens were examined. The mean total length of the preferred fish species ranged 11.73 - $18.63 \mathrm{~cm}$ and mean weight ranged 26.75 - 79.21 g. A. occidentalis fed more on insects (35\%), 0. niloticus fed more on algae (90\%), S. galilaeus showed more preference for algae (80 \% composition). B. imberi preferred plant parts (50\% composition) and M. abadii fed on earthworms and insects with equal composition of $42.1 \%$. Some of the species also fed on sand namely A. occidentalis (20\%), 0. niloticus (10 \%) and M. abadii (10.5 \%). The ability of the preferred fish species to feed on a wide range of food items makes them potential candidates for aquaculture.

Keywords: Diet; Feeding Habit; Fish Morphometry; Libga; Reservoir 


\section{International Journal of Oceanography \& Aquaculture}

\section{Introduction}

Northern Ghana is endowed with numerous rivers and reservoirs of which Libga reservoir is one of them. This reservoir serves a number of functions including watering of livestock, irrigation of crops and as domestic water source to nearby communities. Fisheries resources are also provided by this reservoir which ensures enhanced nutritional health from fish protein and occupational fishing to both local and migrant fishermen from southern Ghana thus providing employment and income to local and migrant fishermen though this is not its intended use. Frequent assessment of the Libga reservoir fishery may be necessary because population size, structure, and distribution fluctuate in response to environmental variation [1].

Biological research of fish species is important for the assessment of probability of culture in water bodies. The morphometric analysis of fish is a vital key in the study of biology of fish. In most fishes, variations in the relative growth of the various body parts are known to occur at distinct stages of development and particularly at sexual maturity [2]. Growth of the body parts is proportional to the growth of the total length. So, morphometric measurement of fishes and the study of relationship among them are important for taxonomic study of a species [3]. The shape and structures are unique to the species and the variations in its feature are probably related to the habit and habitat among the variants of this species [4].

The food and feeding habitat of fish may be an important characteristic of the life-history strategy of a species to know the foremost necessary functional role of the fish inside their living ecosystems [5-8]. The study of the food and feeding habits of freshwater fish species is a subject of continuous research, because it plays a basic integral part in the development of a successful fisheries management programme on fish capture and culture $[9,10]$. Diet compositions are important in community ecology because the use of resources by organisms has a major influence on population interactions within a community according to Mequilla and Campos [11]. Knowledge on the natural food of fish in its habitat is important in order to be aware of its nutritional needs and interaction with other organisms [12]. Again, the understanding of fish diet provides information on grouping of fish with respect to their food, method of feeding, determination of the population parameters of some species that cannot be determined by other methods and subsequent successful culture [13].

Reservoir fisheries cannot be overlooked as far as its nutritional and economic importance is concerned with regards to the riparian community and the nation as a whole. Despite the numerous importances of reservoirs (Libga) in terms of fisheries, catches are declining as human population is increasing whiles the demand for fish and fish resources is increasing [14]. According to Quacoopome T, et al. [15] dwindling catches have become a common problem for over 20 years with possible reasons for their decline being over exploitation of stocks, environmental degradation and low water levels.

To meet this demand for fish, there is a need for management of the stock and also alternative fish sources preferably aquaculture. Unfortunately there is inadequate data on preferred fish species in the Libga reservoir. Thus there is a need to know the food and feeding habits of the preferred fishes and also their morphometry since morphometric studies are not only essential to understand the taxonomy but also the health of a species (including reproduction) [4], in order to lay a foundation for the culture of these fishes since aquaculturists would first of all be interested in the food of these fishes.

\section{Materials and Methods}

\section{Study Area}

The Libga reservoir ( $9035^{\prime} \mathrm{N}, 005^{\prime} \mathrm{W}$ ) (Figure 1) located in the Savelugu District has a surface area of 48 ha at maximum height. It was impounded in 1970 but the wall collapsed in the same year, flooding the downstream areas and subsequent rehabilitation was completed in 1971. Although its main purpose of construction was irrigated agriculture, it is currently being used for a variety of domestic purposes. Besides these benefits, the Libga reservoir is of immense economic importance to the locals and migrants who have developed survival strategies based on access to both fishing and farming [15]. 


\section{International Journal of Oceanography \& Aquaculture}

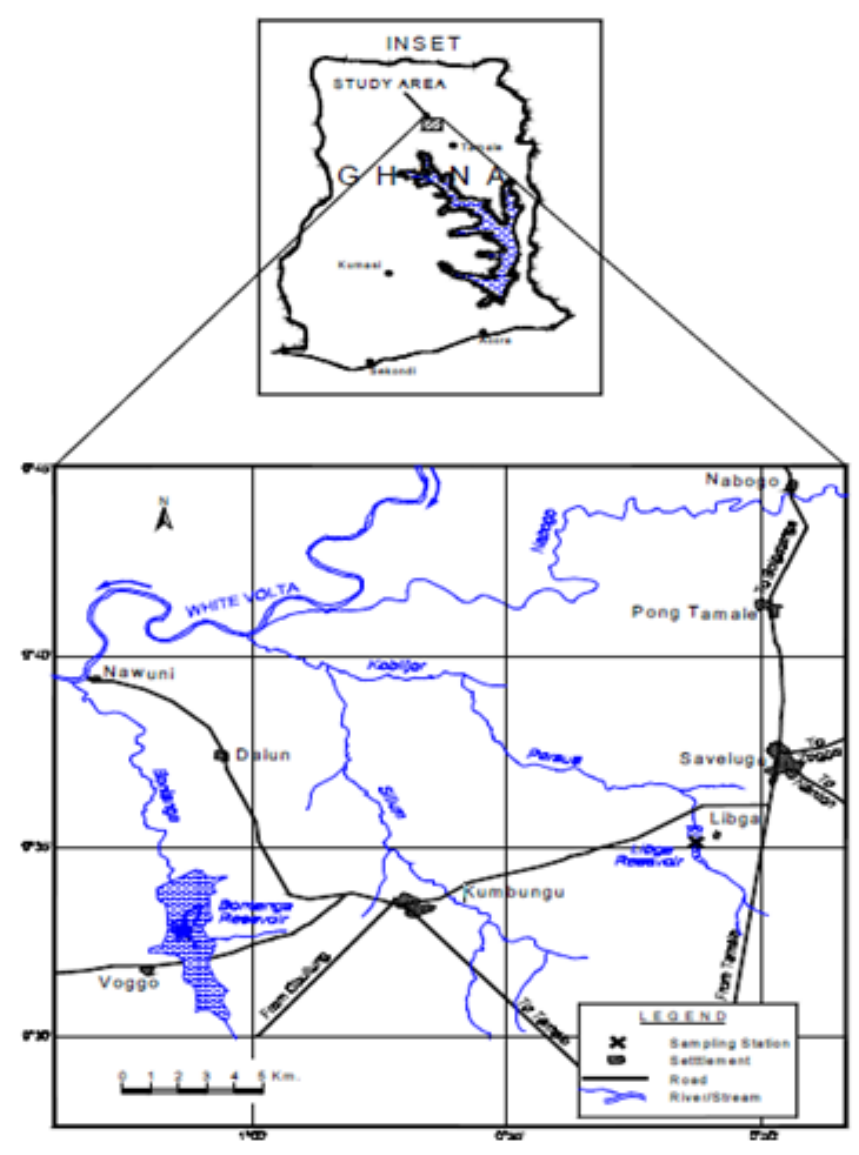

Figure 1: Map of Ghana showing Libga reservoir in northern Ghana, adopted from Quarcoopome T, et al. [15].

\section{Data Collection}

Information on the preferred fish species was obtained with the use of semi-structured interviews. A total of seventeen randomly selected fishermen from the two major landing sites of the reservoir and five fish sellers were interviewed for response on the preferred fish species. Samples of the preferred fish species used for stomach content analysis were purchased from catches of local fishermen using hooks and lines, gill nets, and cast nets in the reservoir. Catches of local fishermen from the reservoir were assessed once every month from December 2015 to May 2016. All fish specimens were still alive as at the time of purchase. Fish samples were preserved with iced block and immediately transported to the laboratory for further analysis. Fish species of economic importance were identified using identification keys provided by Dankwah HR, et al. [16]

\section{Determination of Stomach Contents}

Specimens were dissected and the guts removed, poured out into a petri dish for stomach content analysis. Contents which could not be easily identified using the naked eye or magnifying glass were taken with a dropper and placed on slides and viewed under an electronic microscope.

\section{Data Analysis}

Stomach contents were analysed using the frequency of occurrence and 'points' method [17-19]. The frequency of occurrence method estimates the percentage of stomachs in a sample containing a given food item whereas the 'points' method gives the bulk contribution of each food item to the total food consumed. Points were awarded to each stomach according to its degree of fullness; 10 points for full stomach, 5 for half stomach and 


\section{International Journal of Oceanography \& Aquaculture}

2.5 for quarter filled stomach. Empty stomachs were excluded from the analysis. The total number of points awarded to each stomach was subdivided among the food items present according to their relative contribution to the total stomach content. The percentage composition of each of the food items was determined by summing up the points awarded to the item and dividing it by the total points awarded to all stomachs containing food, and the resulting value expressed as a percentage [20].

The Gut Repletion Index (GRI) was calculated using the formula: No. of non-empty guts/Total no. of specimens $\times 100$ [21].

The data obtained on the stomach contents was analysed using Microsoft Excel and presented using descriptive statistics such as tables and pie charts for easy comparison.

\section{Results and Discussion}

\section{The Preferred Fish Species by Riparian Community}

The result showed that Auchenoglanis occidentalis (Valenciennes, 1840), Brycinus imberi (Peters, 1852), Sarotherodon galilaeus (Günther, 1903), Oreochromis niloticus (Linnaeus, 1758) and Marcusenius abadii (Boulenger, 1901) were the preferred fish species and the reason for their choice was good taste, as such, these fish species are easily patronised for quick income to the fishermen (Figure 2).

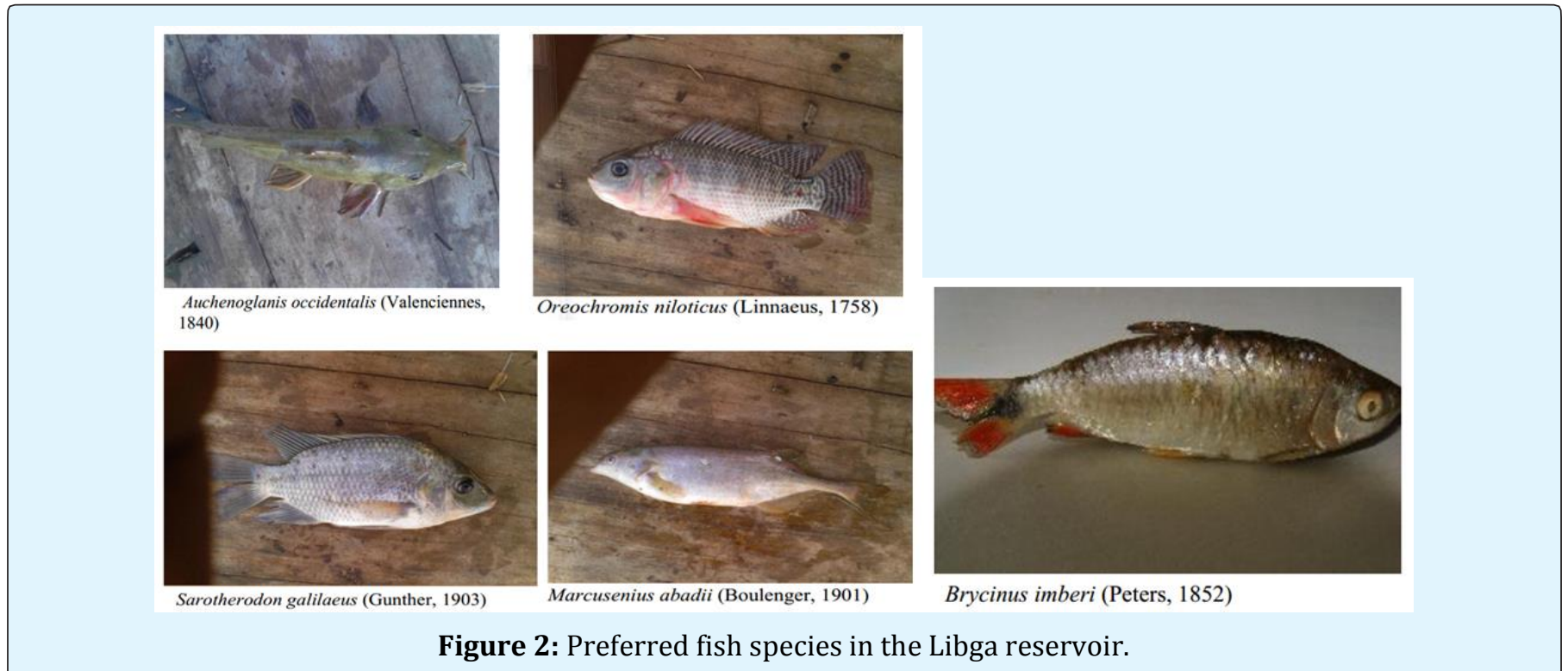

\section{Morphometry of the Preferred Fish Species}

Out of a total of 223 specimens examined, 49 were Auchenoglanis occidentalis, 56 Brycinus imberi, 66 Sarotherodon galilaeus, 30 Oreochromis niloticus and 22 Marcusenius abadii. This showed that the samples were dominated by Sarotherodon galilaeus species with Marcusenius abadii being the least (Figure 3). Auchenoglanis occidentalis recorded the highest mean total length and weight of $18.6 \mathrm{~cm}$ and $79.2 \mathrm{~g}$ respectively and Marcusenius abadii recorded the least mean weight of $26.75 \mathrm{~g}$ while Sarotherodon galilaeus recorded the least mean total length of $11.7 \mathrm{~cm}$ with $80 \%$ of the species recording their highest mean total length in March (Table 1).

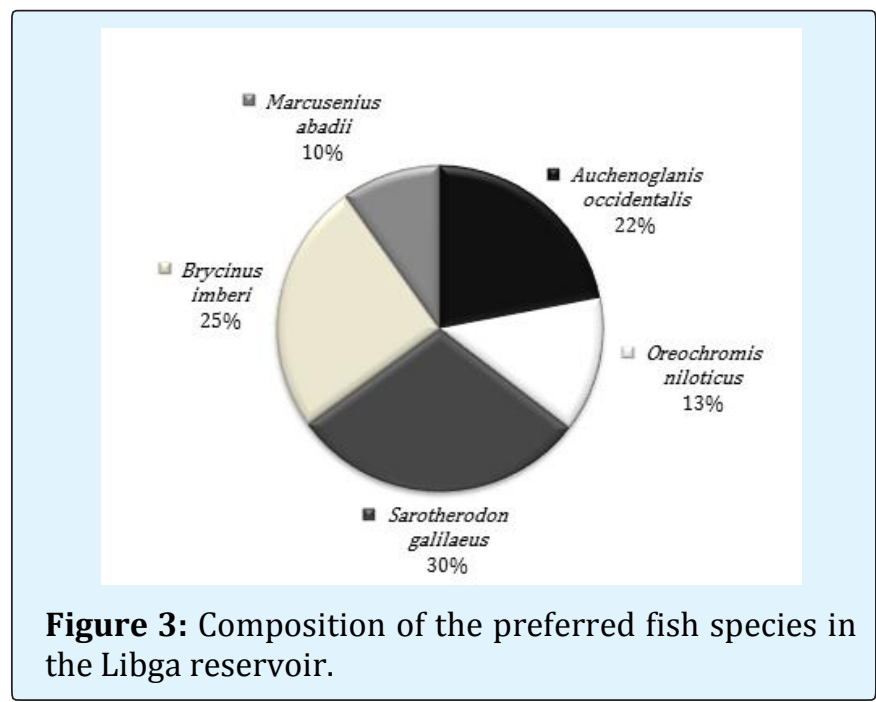




\section{International Journal of Oceanography \& Aquaculture}

\begin{tabular}{|c|c|c|c|c|c|c|c|c|c|}
\hline \multirow{2}{*}{ Species } & \multirow{2}{*}{ N } & \multicolumn{3}{|c|}{ Total Length, TL/cm } & \multicolumn{3}{c|}{ Weight/g } & \multicolumn{2}{c|}{ Month } \\
\cline { 3 - 10 } & & Max & Min & Mean & Max & min & mean & Max & Min \\
\hline Auchenoglanis occidentalis & 49 & 28.2 & 13.5 & 18.6 & 259 & 26 & 79.2 & Mar & Feb \\
\hline Oreochromis niloticus & 30 & 20 & 6.2 & 12 & 151.5 & 4.24 & 41.2 & Mar & Dec \\
\hline Sarotherodon galilaeus & 66 & 16.5 & 6.5 & 11.7 & 82.7 & 5.2 & 37.5 & Mar & Dec \\
\hline Brycinus imberi & 56 & 18.3 & 10 & 13 & 64 & 10.4 & 28.1 & Mar & Jan \\
\hline Marcusenius abadii & 22 & 16.1 & 10 & 14.7 & 39 & 18 & 26.75 & Dec & Feb \\
\hline
\end{tabular}

Table 1: Summary of weight and length distributions of the preferred fish species.

The maximum total length and maximum weight of Auchenoglanis occidentalis specimen was $28.2 \mathrm{~cm}$ and 259.01 g respectively (Table 1) compared to that recorded by Onimisi $\mathrm{HU}$, et al. [22] (37.5 $\mathrm{cm}$ total length and $800 \mathrm{~g}$ maximum weight) in Zaria reservoir, Nigeria suggesting that the species caught from the Libga reservoir were small in size. The differences in the length and weight of the species may be due to the high level of exploitation. The minimum total length of fish $(13.5 \mathrm{~cm})$ maybe due to the selectivity of the mesh sizes of the nets used to capture the fish [23].

It was observed that the maximum weight of Oreochromis niloticus was 151.52 g (Table 1) from the Libga reservoir. This was in contrast to that recorded by Imam TS, et al. [24], who recorded a maximum weight of $50 \mathrm{~g}$ for Oreochromis niloticus in Wasai reservoir, Nigeria. However, the average weight of the fish during the study was $41.16 \mathrm{~g}$ which means that most of the fish captured were small sized with only few big ones. This might be due to the selectivity of the fishing gear used to capture the fish species.
The mean total length of Sarotherodon galilaeus was $11.73 \mathrm{~cm}$ (Table 1) compared to that recorded by Adedeji $\mathrm{HA}$, et al. [25], $(16.23 \pm 1.41 \mathrm{~cm})$, showing that most of the fish were under size at the time of capture and it was the same for the mean body weight. The total length of Brycinus imberi ranged 10-18.3 cm (Table 1) compared to that of its close relative Brycinus nurse recorded by Abobi $\mathrm{SM}$, et al. [26], $(6.5-27.5 \mathrm{~cm})$ showed that the fish species captured in Libga reservoir were medium sized. The total length of Marcusenius abadii ranged 10-16 cm (Table 1) indicating that the fish were small sized which might be due to the selectivity of the mesh sizes of the nets and over-exploitation.

\section{Food Items Consumed by the Preferred Fish Species}

The Gut Repletion index of the preferred fish species ranged from $30 \%$ to $63.6 \%$ (Table 2). This showed that all the species are non-active feeders and have lower energy requirement to sustain this level of feeding intensity [27].

\begin{tabular}{|c|c|c|c|c|c|c|}
\hline \multirow{2}{*}{ Species } & \multicolumn{4}{|c|}{ \% Occurrence } & GRI \\
\cline { 2 - 8 } & Empty & Quarter & Half & Three-quarter & Full & $(\%)$ \\
\hline Auchenoglanis occidentalis & 68 & 6 & 10 & 4 & 12 & 32.7 \\
\hline Oreochromis niloticus & 70 & 0 & 10 & 0 & 20 & 30 \\
\hline Sarotherodon galilaeus & 71 & 12 & 6 & 5 & 6 & 30.3 \\
\hline Brycinus imberi & 84 & 5 & 7 & 0 & 4 & 16.1 \\
\hline Marcusenius abadii & 36 & 9 & 9 & 0 & 46 & 63.6 \\
\hline
\end{tabular}

Table 2: Percentage distribution of stomach contents of the preferred fish species in the Libga reservoir.

The results from this study showed that Auchenoglanis occidentalis consumed variety of food items ranging from insects, sand, earthworms, plant parts and algae (Figure 4). This was similar to Onimisi $\mathrm{HU}$, et al. [28], who reported that Auchenoglanis occidentalis from Zara reservoir fed on a variety of food such as insect larvae and pupae and plant material including detritus making the fish omnivorous. This result also showed that
Auchenoglanis occidentalis was a bottom feeder. It was also observed in this study that the fish fed more on insects and earthworms than other food items and this preference could be due to the fact that these food items were dominant in the reservoir. The high percentages of empty stomachs encountered during the study maybe due to the fact that the foods eaten were soft and were easily digested. This might also be as a result of the fishes been 
captured the evening before sampling hence long period of struggling making them expend more energy [29].

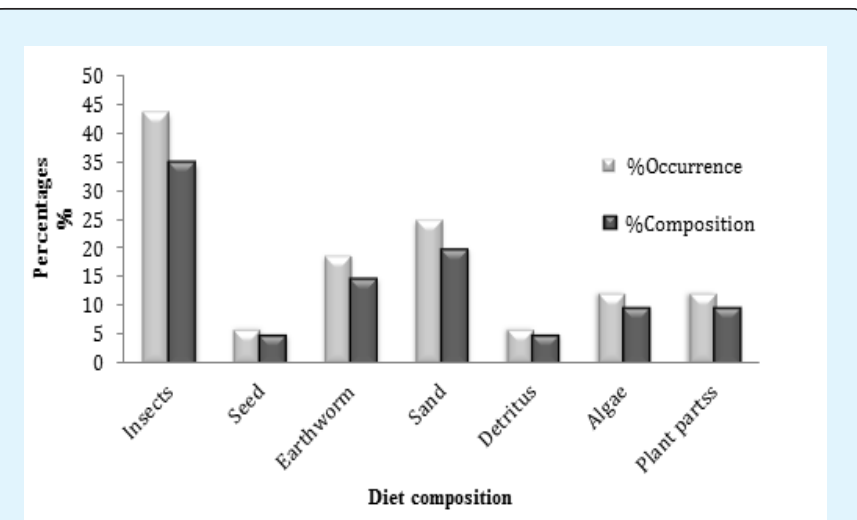

Figure 4: Composition and frequency of occurrence of stomach contents of Auchenoglanis occidentalis in the Libga reservoir from December 2015 to April 2016.

Oreochromis niloticus fed exclusively on green algae with only one of the fish feeding on sand (Figure 5). This was in contrast to Oso JA, et al. [9], who suggested that Oreochromis niloticus was omnivorous feeding on a wide range of macrophytes, green algae, detritus, sand grains, insect parts etc. and that of Abdulhakim, A et al. [30] who said that the major food items of Oreochromis niloticus in Lake Alau were mainly herbs, algae and fish remains. The contrasting feeding habits of the fish may be due to the differences in the abundance of the food items in the different locations. The feeding habits were also different from those reported by Fagade SO and Olaniyan [31] in the Lagos lagoon. However, Abdulhakim A, et al. [30] also discovered sand or mud in the gut of Oreochromis niloticus and this indicated that the fish is a bottom feeder.

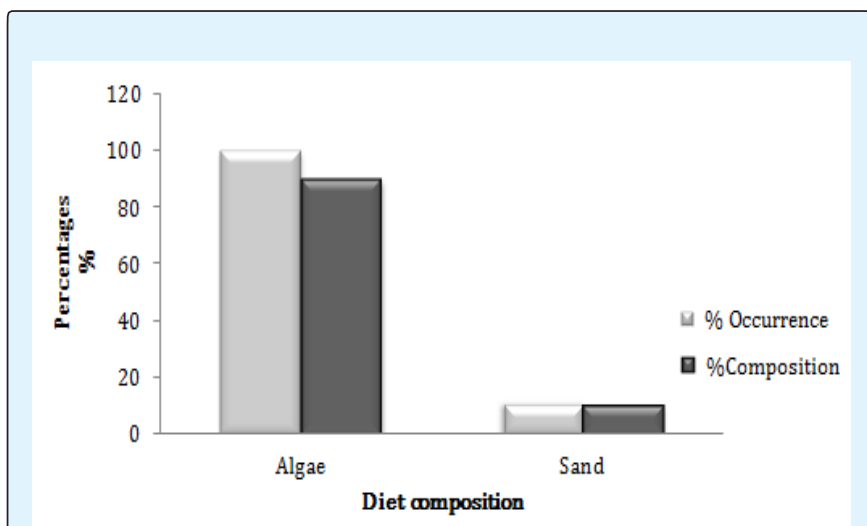

Figure 5: Composition and frequency of occurrence of stomach contents of Oreochromis niloticus in the Libga reservoir from Dec 2015 to April 2016.
The result of the study showed that Sarotherodon galilaeus fed mainly on green algae and plant parts (Figure 6). This did not differ markedly from Oso JA, et al. [9], who suggested that Sarotherodon galilaeus was omnivorous feeding on a wide range of macrophytes, green algae, detritus, sand grains, insect parts etc. However, this was in contrast with Ajala 0, et al. [32], who reported that Sarotherodon galilaeus had preference for food items of animal origin in both immature and matured stages.

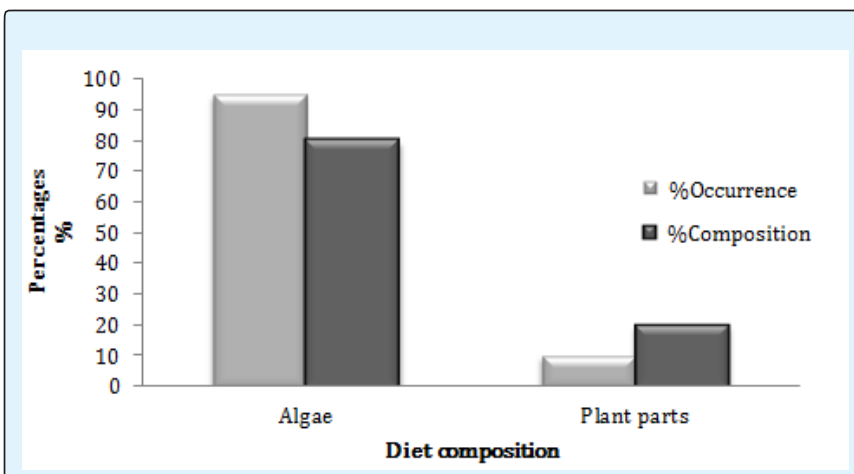

Figure 6: Composition and frequency of occurrence of stomach contents of Sarotherodon galilaeus in the Libga reservoir from Dec 2015 to April 2016.

The study showed that Brycinus imberi fed on algae, insects and plant parts being the dominant food item (Figure 7). This made the fish omnivorous feeding on a range of food items. This agreed with N'da AS, et al. [33] who said Brycinus leuciscus was omnivorous. This also was similar to that recorded in its close relative Brycinus nurse by Saliu JK [34]. The trophic status of the fish indicated that it was omnivorous and consequently it fed on a broad spectrum of food items, a feature that similarly occurred in its other close relatives.

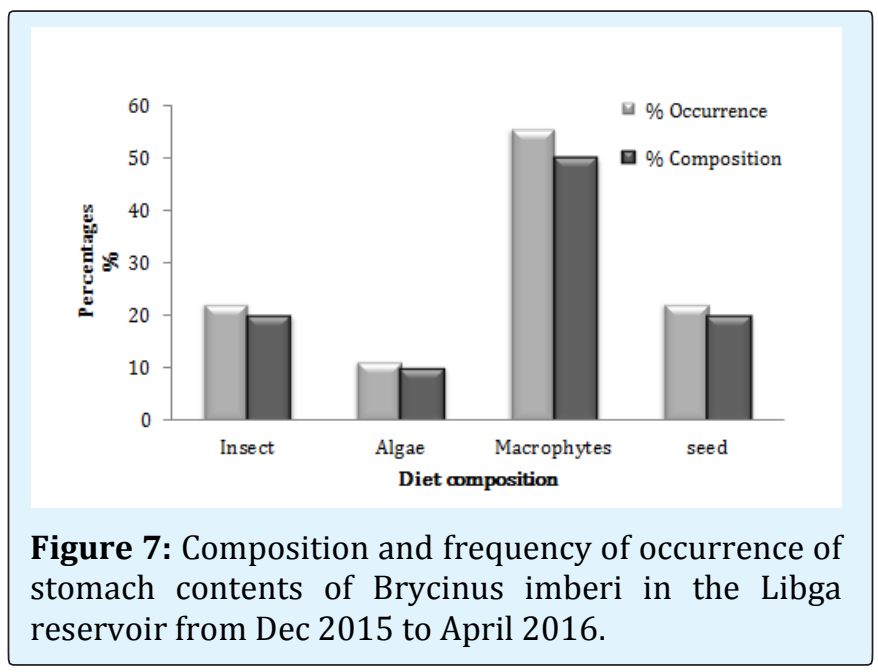




\section{International Journal of Oceanography \& Aquaculture}

Marcusenius abadii in Libga reservoir fed on a wide range of food items namely insects, plant parts, earthworms and sand with insects been the dominant food item (Figure 8).This indicated that the fish was an omnivore and a bottom feeder. This did not differ from the findings of Kouamelan EP, et al. [35] who asserted that Marcusenius species fed on chironomid larvae.

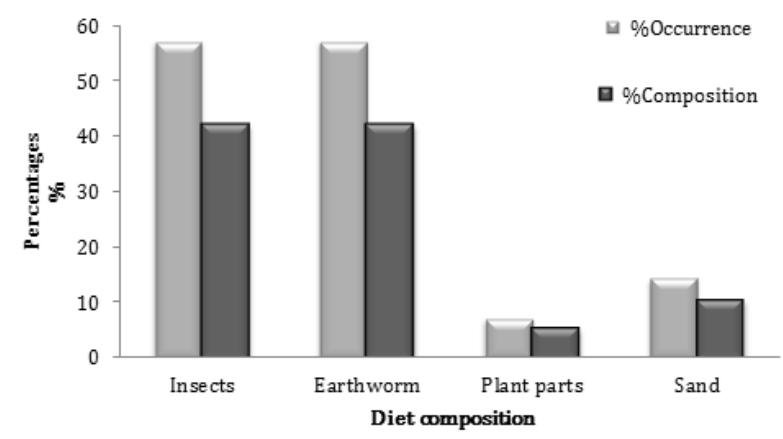

Figure 8: Composition and frequency of occurrence of stomach contents of Marcusenius abadii in the Libga reservoir from Dec 2015 to April 2016.

\section{Conclusion}

The sizes of the preferred fish species sampled during the study were relatively small and this may be due to the type of fishing gear used and size-selectivity of the mesh of the nets used. The result indicated that the fishes fed on wide range of food items though most of their stomach at the time of study was empty which may probably be due to long hours of struggling after capture. Most of the species from the results were omnivores. The ability of the economic fish species to feed on a wide range of food items means there is less interspecific competition in the reservoir and probably makes them possess a high aquaculture potential. This is particularly important for the culture of these species, since it is possible to formulate artificial diets necessary for their mass production. The non-specific feeding habit of these fish species is what has accounted for their wide distribution and abundance in the Libga reservoir. It can be concluded that the preferred fish species in the Libga reservoir utilize more than one source of food.

It was recommended that studies should be done on other aspects of the fishes such as the reproduction of the species in order to aid their culture. Extended study of this research should be carried out on these species for a year to bring into light possible inherent factors leading to this observation.

\section{References}

1. McRae BJ, Diana JS (2005) Factors influencing density of age- 0 Brown Trout and Brook Trout in the Au Sable River, Michigan. Transactions of the American Fisheries Society 134(1): 132-140.

2. Hussain MA, Khatun MA, Siddique MAB, Flowra FA, Alam MM, et al. (2012) Morphometric characters of freshwater fish Xenentodon cancila collected from Rajshahi city, Bangladesh. Journal of Biological Sciences 20: 171-177.

3. Tandon KK, Johal MS, Bala S (1993) Morphometry of Cirrhinusreba (Hamilton) from Kanjli wetland, Punjab, India. Research Bulletin Punjab Universal Science 43(1-4): 73-78.

4. Subramanian P (2011) An anthology of articles on aquatic research. Nitheeshpraba Pathippagam, Karaikudi, India, pp: 164.

5. Blaber SJM (1997) Fish and Fisheries of Tropical Estuaries. Chapman and Hall, London, pp: 367.

6. Cruz EVH, Abittia CLA, Campos DL, Galvan MF (2000) Trophic interrelations of the three most abundant species from Laguna San Ignacio, Baja California Sur, Mexico. Bulletin of Marine Science 66(2): 361-373.

7. Hajisamae S, Chou LM, Ibrahim S (2003) Feeding habits and trophic organization of the fish community in shallow waters of an impacted tropical habitat. Estuarine Coastal and Shelf Science 58(1): 89-98.

8. Abdel-Aziz NE, Gharib SM (2007) Food and feeding habits of round Sardinella (Sardinella aurita) in ElMex Bay, Alexandria. Egypt. Egyptian Journal of Aquatic Research 33(2): 202-221.

9. Oso JA, Ayodele AI, Fagbuaro O (2006) Food and feeding habits of Oreochromis niloticus (L.) and Sarotherodon galilaeus (L.) in a tropical reservoir. World Journal of Zoology 1(2): 118-121.

10. Oronsaye CG, Nakpodia FA (2005) A Comparative study of the food and feeding habits of Chrysichthys nigrodigitatus and Brycinus nurse in a Tropical River. Pakistan Journal of Science and Industrial Research 48: 118-121. 


\section{International Journal of Oceanography \& Aquaculture}

11. Mequilla AT, Campos WL (2007) Feeding relationships of dominant fish species in Visayan Sea. Science Diliman 19(1): 35-46.

12. Alhassan EH, Commey A, Bayorbor TB (2011) An Investigation into the food and feeding habits of Sarotherodon galilaeus (Pisces: Cichlidae) in a Shallow Tropical Reservoir. Research Journal of Fisheries and Hydrobiology 6(2): 74-77.

13. Abowei JFN (2010) Salinity, dissolved oxygen, $\mathrm{pH}$ and surface water temperature conditions in Nkoro River, Niger Delta, Nigeria. Advance Journal of Food Science and Technology 2(1): 360-400.

14. FAO (2010) The state of world fisheries and aquaculture. Part 3, Highlights of Special Cases: 115188.

15. Quarcoopome T, Amevenku FYK, Ansa-Asare OD (2008) Fisheries and limnology of two reservoirs in Northern Ghana. West African Journal of Applied Ecology 12(1): 61-80.

16. Dankwah HR, Abban EK and Teugels GG (1999) Fresh water fishes of Ghana: identification, distribution, ecological and economic importance. Anales Science Zoology pp: 283.

17. Bagenal TB, Braum E (1978) Eggs and Early Life History. In: Bagenal T (Eds.), Methods for the Assessment of Fish Production in Freshwater $3^{\text {rd }}$ (Edn.), Oxford Blackwell Scientific Publication Ltd, pp: 165-201.

18. Hyslop EJ (1980) Stomach content analysis-a review of methods and their application. Journal of Fish Biology 17(4): 411-429.

19. Lima- Junior SE, Goitein R (2001) A new method for the analysis of fish stomach contents. Maringá 23(2): 421-424.

20. Atindana SA, Bulley R, Alhassan EH, Abarike ED, Yeboah AA, et al. (2014) Stomach content analysis of Tilapia zillii and Hemichromis fasciatus in the Golinga Reservoir in the Tolon District in the Northern Region of Ghana. Proceedongs of the 32nd Biennial Conference of the Ghana Animal Science Association pp: 23-28.

21. Ekpo IE, Essien-Ibok MA, Nkwoji JN (2014) Food and feeding habits and condition factor of fish species in Qua Iboe River Estuary, Akwa Ibom State, south- eastern Nigeria. International Journal of Fisheries and Aquatic Studies 2(2): 38-46.

22. Onimisi HU, Oniye SJ (2010) Length-weight relationship and condition factor of Auchenoglanis occidentalis (Valenciennes, 1840) in Zaria, Nigeria. Zoologist 8: 52-56.

23. Usman IB (2012) Length-weight relationship of Auchenoglanis occidentalis (Family:Bagridae) in Kontagora Reservoir, Niger State, Nigeria. Journal of Fish International 7(1): 16-19.

24. Imam TS, Bala U, Balarabe ML and Oyeyi TI (2010) Length-weight relationship and condition factor of four fish species from Wasai reservoir in Kano, Nigeria. African Journal of General Agriculture 6(3): 125-130.

25. Adedeji HA, Hyginus MD, Idowu TA, Sogbesan OA (2016) Growth pattern and condition factor of Oreochromis niloticus and Sarotherodon galilaeus in Lake Geriyo, Adamawa State. International Journal of Life Sciences Research 4(1): 97-99.

26. Abobi SM, Ekau W (2013) Length-weight relationships and condition factors of Alestes baremoze, Brycinus nurse and Schilbe intermedius from the Lower Reaches of White Volta River (Yapei), Ghana. International Journal of Fisheries and Aquaculture 5(6): 152-165.

27. King RP, Udodiong OM, Ekwali EC, Nkanta NA (1991) Some aspects of the trophic Biology of IIisha Africana (Teleostei, Pristigasteridae) in Qua Iboe Estuary, Nigeria. African Journal of Ecology 105: 261-274.

28. Onimisi HU, Oniye SJ, Balogun, JK, Aken Ova TOL (2009) Food and feeding habits of Auchenoglanis occidentalis (Valenciennes, 1840) in Zara, Nigeria. Zoologist 7: 57-64.

29. Arawomo GAO (1976) Food and feeding of three Citharinus species in Lake Kainji, Nigeria. Journal of Fish Biology 9: 3-10.

30. Abdulhakim A, Addo S, Lawan AZ, Addi E (2015) Feeding habits and condition factor of Oreochromis niloticus in Lake Alau, Northeastern Nigeria. International Journal of Fisheries and Aquatic Studies 3(1): 406-409.

31. Fagade SO (1983) The food and feeding habits of the fishes of Lower River Benue Nigeria. Bulletin De I' FAN 45: $316-341$. 


\section{International Journal of Oceanography \& Aquaculture}

32. Ajala O, Fawole O, Olatunde 0 (2015) Diets and enter parasitic infestation in Sarotherodon galilaeus (Linnaeus, 1758) (Cichlidae) in Oba Reservoir Ogbomoso, Nigeria. International Journal of Fisheries and Aquatic Studies 2(6): 3-10.

33. N'da AS, Nzi KG, Berte S, Kouamelan EP, N'Douba V (2016) Length-weight relationship, condition factor and feeding habits of Brycinus leuciscus (Günther, 1867) (Characidae) in Bagoe River, Cote D' Ivoire. International Journal of Applied Biology and Pharmaceutical Technology 7(1): 161-168.
34. Saliu JK (2002) Size, sex and seasonal dynamics in the dietary composition of Brycinus nurse (Pisces: Characidae), from Asa Reservoir, Ilorin, Nigeria. Rev Biol Trop 50(1): 233-238.

35. Kouamelan EP, Kone T, N'Douba V and Ollevier F (2015) Food habits and trophic resource partitioning among three Mormyrid Fishes from man-made Lake Ayame, Ivory Coast. African Zoology 41(2): 266-274. 